\title{
Factors controlling seasonal succession of the copepods Acartia hudsonica and A. tonsa in Narragansett Bay, Rhode Island: temperature and resting egg production
}

\author{
Barbara K. Sullivan \& Liana T. McManus \\ Graduate School of Oceanography, University of Rhode Island, Narragansett, Rhode Island 02882, USA
}

\begin{abstract}
We present evidence to show that the timing of the seasonal appearance and disappearance of Acartia hudsonica, the dominant winter-spring copepod in Narragansett Bay, a north temperate estuary, is controlled by temperature and its effect on reproductive rate and formation and hatching of resting eggs. Maximum reproductive rates and growth efficiency for this species were observed at temperatures below those typical of the mid-summer season when it is replaced by Acartia tonsa, the summer dominant. Furthermore, during early summer $A$. hudsonica produces eggs that do not hatch at the temperatures at which they are produced $\left(>16^{\circ} \mathrm{C}\right)$ and that will hatch only after exposure to low temperature. These eggs were also present in the sediments of Narragansett Bay and are probably true diapause eggs. It also appears that competition for food is not an important factor controlling seasonal succession of the species. Populations of both Acartia species were observed in $13 \mathrm{~m}^{3}$ enclosed ecosystems which differed from Narragansett Bay in that food supply was increased by addition of nutrients. Timing of the seasonal transition between $A$. hudsonica and $A$. tonsa was not altered in any consistent way by these changes, although population size increased in some years.
\end{abstract}

\section{INTRODUCTION}

The mechanisms actually responsible for seasonal patterns in abundance of marine zooplankton species are poorly understood because of the difficulty in obtaining information on how rates of birth and death, and therefore population growth potential, change with season or interspecific predation or competition. We present data on reproductive rates of Acartia hudsonica Pinhey, locally referred to as $A$. clausi until redescribed (Bradford 1976), and A. tonsa Dana, respectively the winter-spring and summer-fall dominant copepods in Narragansett Bay, Rhode Island, obtained from populations contained in $13 \mathrm{~m}^{3}$ experimental ecosystems in which we could examine some of these factors with more control than is usually possible in field studies.

The geographical and seasonal patterns of distribution of Acartia tonsa and A. clausi, 2 widely distributed and abundant species in estuarine and neritic regions, have been well documented for the east coast of North America (Conover 1956, Jeffries 1962, Lee \& McAlice
1979). These studies indicate a clear association with temperature in that $A$. clausi is successful only in colder climates while $A$. tonsa is found year round only in warmer waters further south. In areas where the 2 species co-occur it has been hypothesized that differences in optimal temperature or salinity keep the niches of the 2 species separate (Conover 1956, Jeffries 1962) and control their seasonal replacement. Lee \& McAlice (1979), however, report that both species coexist and have peak abundances during the same season in a Maine estuary. The pattern they describe suggests that competitive exclusion by $A$. tonsa is not an important process.

The evidence that Acartia tonsa produces resting or dormant eggs in response to cold temperatures in northern sections of its range (Zillioux \& Gonzales 1972) indicates the potential for this genus to use dormancy as a mechanism to regulate its seasonal occurrance in Narragansett Bay. There has been no similar study to examine the potential for A. hudsonica to produce dormant eggs. Laboratory manipulations of eggs from female $A$. hudsonica and from sediments 
taken from Narragansett Bay and $13 \mathrm{~m}^{3}$ MERL enclosures indicate that this species also produces resting eggs, but in response to warm temperatures.

Temperature is clearly an important mechanism controlling reproductive rates and population success and therefore timing of succession of both of these species in Narragansett Bay. Manipulations of the mesocosms during a study of nutrient effects showed that food supply may modify the size of seasonal peaks but not the timing of the seasonal transition between species, further indicating that temperature, not competition for food, is an important mechanism controlling seasonal succession.

\section{METHODS}

The MERL mesocosms used for this study were part of a $2.5 \mathrm{yr}$ study of the effects of nutrient loading on shallow marine ecosystems (Nixon et al. 1984). MERL mesocosms are $13 \mathrm{~m}^{3}$ tanks scaled to the natural system, Narragansett Bay, Rhode Island, in terms of sunlight, temperature, tidal mixing and flushing $(3.7 \%$ volume exchange of unfiltered bay water per day). The tanks contain both sediment and water column communities and while they have a slow exchange of seawater, any ecosystem changes resulting from controlled perturbation of the tanks can be observed and quantified. It has been demonstrated that in many respects the MERL systems mimic the natural systems, maintaining similar concentrations of nutrients, phytoplankton and zooplankton biomass throughout the annual cycle (Pilson et al. 1979, 1980). Salinity in these systems reflects conditions near the mouth of Narragansett Bay, never varying outside of a narrow range of 29 to $32 \%$.

For the nutrient enrichment experiment, nutrients were added daily to 6 tanks to provide input rates that were multiples $(1 \times, 2 \times, 4 \times, 8 \times, 16 \times, 32 \times)$ of the average annual nutrient loading to Narragansett Bay calculated on a per square meter basis. Three control tanks were left untreated at ambient nutrient levels. Solutions of $\mathrm{NH}_{4} \mathrm{Cl}, \mathrm{KH}_{2} \mathrm{PO}_{4}$ and $\mathrm{Na}_{2} \mathrm{SiO}_{3} .7 \mathrm{H}_{2} \mathrm{O}$ were added in a molar ratio of $12.8 \mathrm{~N}: 1.0 \mathrm{P}: 0.9 \mathrm{Si}$ simulating ratios in sewage (Nixon et al. 1984). Additions to each treatment were multiples of the $1 \times$ level which was $7.57,0.59,0.54 \mathrm{mmol} \operatorname{tank}^{-1} \mathrm{~d}^{-1}$ of $\mathrm{N}, \mathrm{P}$, and Si.

Zooplankton abundances and species composition were estimated from weekly net tows (2 replicates) sampling from bottom to top of each tank $(5 \mathrm{~m}$ deep water column). Nets were $30 \mathrm{~cm}$ diameter, $64 \mu \mathrm{m}$ mesh, and sampled $0.25 \mathrm{~m}^{3}$ per tow. Subsampling was done with a Stempel pipette to produce a count of 200 or more animals.

Females used for egg production were taken from the MERL tanks by gentle net tows, sorted out from other copepods, and incubated in tank water filtered through a $64 \mu \mathrm{m}$ mesh in $1.0 \mathrm{lglass}$ jars (10 females per jar), and placed on a rotating plankton wheel. Ambient temperature and photoperiod provided by fluorescent lighting of approximately $30 \mathrm{~lx}$ was used. Eggs were collected within $16 \mathrm{~h}$ and counted out into $30 \mathrm{ml}$ glass culture dishes. Observations for hatched nauplii were made under a dissecting microscope and any nauplii were removed. Temperature was kept near ambient bay water by keeping dishes in a water bath next to the microscope.

Dry weight of the females was determined on groups of 10 individuals, rinsed in $0.45 \mu \mathrm{m}$ filtered seawater prior to gentle filtration onto preweighed $3 \mu \mathrm{m}$ pore size filters. Salt was removed with a drop of deionized water, and filters were oven dried at $60^{\circ} \mathrm{C}$. They were weighed to the nearest $2 \mu \mathrm{g}$ per filter.

Sediment samples were collected with a coring device with a $2.5 \mathrm{~cm}$ inner diameter and especially designed to prevent disturbance and permit collection of the surface sediments (Frithsen et al. 1983). Cores (2 per tank sampled) were brought to the surface and immediately processed to prevent temperature change. The top of the core was extruded from the core tube so that the first and second $1.0 \mathrm{~cm}$ layers were removed separately. The sample was sieved through $64 \mu \mathrm{m}$ mesh to remove large animals, diluted to $100 \mathrm{ml}$ with $1.0 \mu \mathrm{m}$ filtered seawater, and two $10 \mathrm{ml}$ subsamples withdrawn. The eggs and sediment were incubated together in $50 \mathrm{ml}$ glass culture dishes in a temperature controlled chamber set at ambient temperature and photoperiod. Incubations at other than ambient temperature took place in a separate incubator with no light source. At 2 to 5 d intervals (depending on incubation temperature) the seawater was drawn off without disturbing the sediment and any hatched nauplii were counted. New water was added to restore the dishes to original conditions. To determine the species of nauplii which hatched from the sediments, 50 to 100 nauplii were randomly withdrawn and placed into 1.01 glass culture vessels containing tank water filtered through a $44 \mu \mathrm{m}$ mesh net. These nauplii were reared at ambient temperature and photoperiod until they reached late copepodid or adult stage. Water was renewed every few days to replenish the food supply

\section{RESULTS}

Timing of the seasonal shifts in species composition for the 2 Acartia species in control MERL mesocosms was similar during the 3 yr study (Fig. 1). A. hudsonica, which was most abundant in winter and spring, declined to less than $100 \mathrm{~m}^{-3}$ during mid-July to midAugust. Not until November or December did abun- 

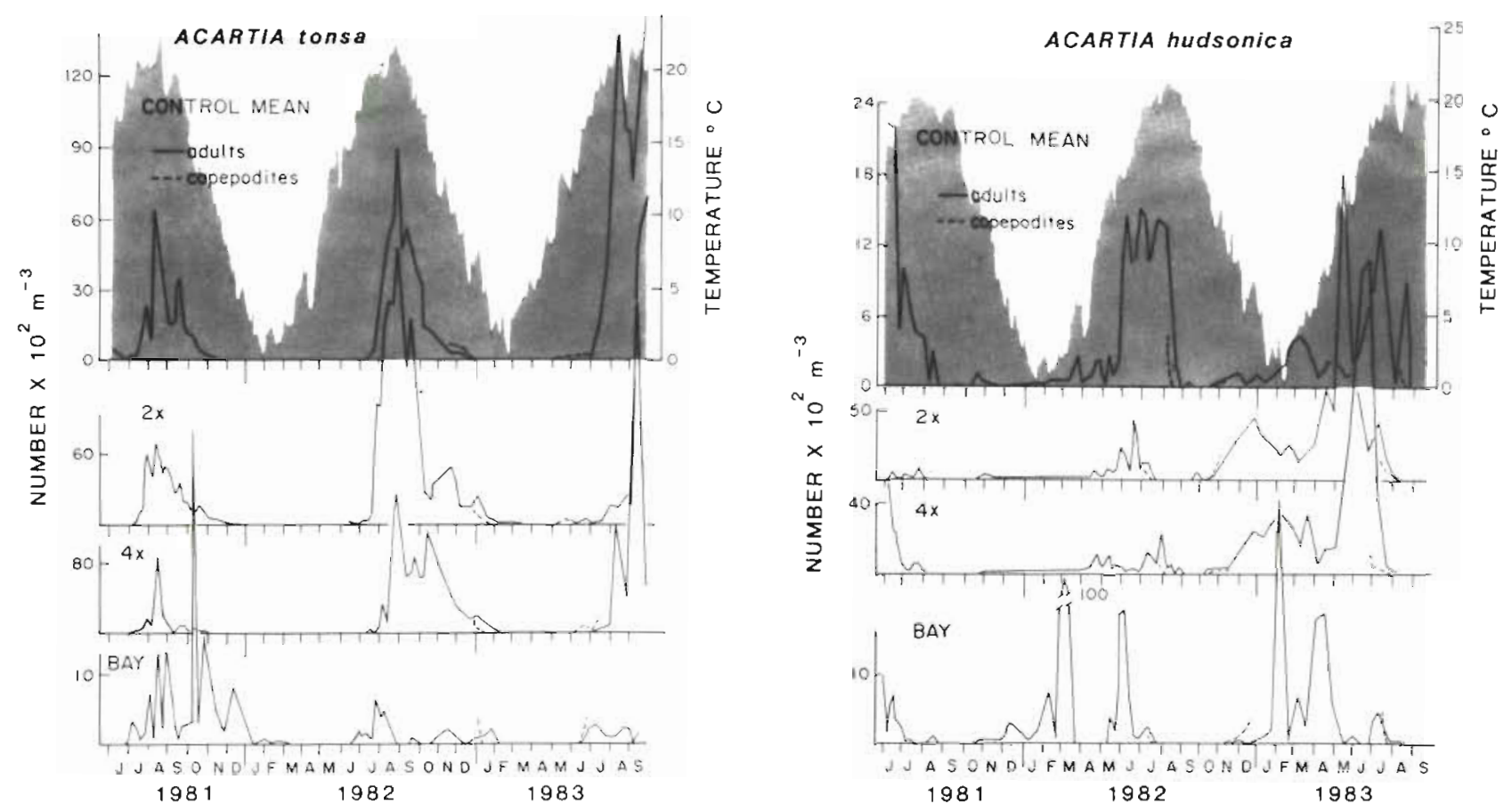

Fig. 1. Acartia hudsonica and A. tonsa. Seasonal patterns of abundance of adults and copepodites in Narragansett Bay and in control and nutrient-enriched MERL mesocosms during a continuous $2.5 \mathrm{yr}$ long experiment. Control pattern is the mean of 3 control tanks. $1 \times$ treatment fell at all times within the control range. Data on numbers of nauplii not available. Water column temperatures indicated by shaded zone

dances increase to greater than $10 \mathrm{~m}^{-3}$. A. tonsa appeared $\left(>10 \mathrm{~m}^{-3}\right)$ in mid-June, was most abundant in August and declined $\left(<100 \mathrm{~m}^{-3}\right)$ during midOctober to mid-December. This is very similar to the pattern of abundances observed for Narragansett Bay at the MERL dock station (Fig. 1) with 2 exceptions. First, the seasonal maximum of $A$. hudsonica occured earlier in the Bay (during March or April) and was thus more separated in time from the period during which A. tonsa is abundant. Second, A. tonsa in Narragansett Bay did not show the well-defined seasonal peak in August that was obvious in the tanks, being present more sporadically throughout the summer.

Abundances but not timing of seasonal species shifts were related to nutrient level of the MERL mesocosms. In nutrient-enriched mesocosms where phytoplankton standing stocks were significantly higher than in controls (Nixon et al. 1984, Sullivan \& Ritacco 1985) the size of the copepod populations was (in some years) increased. This is especially apparent for Acartia hudsonica for which the winter population was greatly enhanced during 1982-1983 (Fig. 1). Timing of the seasonal shifts between the 2 Acartia species in different MERL tanks did not appear to be related to nutrient treatment and hence, food availability, however. While there were some differences among tanks in this timing, there was no consistent change in the pattern related to nutrient treatment.
Peak numbers of Acartia hudsonica in MERL mesocosms occurred just after the seasonal warming to $16^{\circ} \mathrm{C}$ (Fig. 1). Numbers declined in July when temperatures were $20^{\circ} \mathrm{C}$ or higher. Maximum reproductive rates occurred at $15^{\circ} \mathrm{C}$ for this species (Fig. 2). The temperature at which $A$. tonsa exhibited maximum reproductive rates was higher, $20^{\circ} \mathrm{C}$. Comparisons of reproductive rates of the 2 species during periods in which they co-occur further indicate different production efficiencies at the same temperature (Table 1). At warm temperatures $A$. tonsa had higher reproductive rates than $A$. hudsonica regardless of food resources, while at colder temperatures the reverse was true.

Hatching success of eggs laid by Acartia hudsonica was generally higher in early spring (at low temperature) than in late spring and summer (Table 2). No morphological difference among eggs was apparent. To determine whether the eggs which failed to hatch immediately were infertile, dead, or whether they were resting eggs, we incubated 1 group at lower temperature $\left(4\right.$ to $6{ }^{\circ} \mathrm{C}$ ) while another was kept at ambient $\left(20^{\circ} \mathrm{C}\right)$ as a control. After $>7$ and $<10 \mathrm{~d}$ at the lowered temperature (Fig. 3) most of the eggs hatched synchronously, while a few hatched at later dates. Eggs held at $20^{\circ} \mathrm{C}$ failed to hatch until they too were transferred to lower temperature. Some of these eggs may not have survived the incubation at $20^{\circ} \mathrm{C}$ as the total hatch of this group tended to be lower than for 


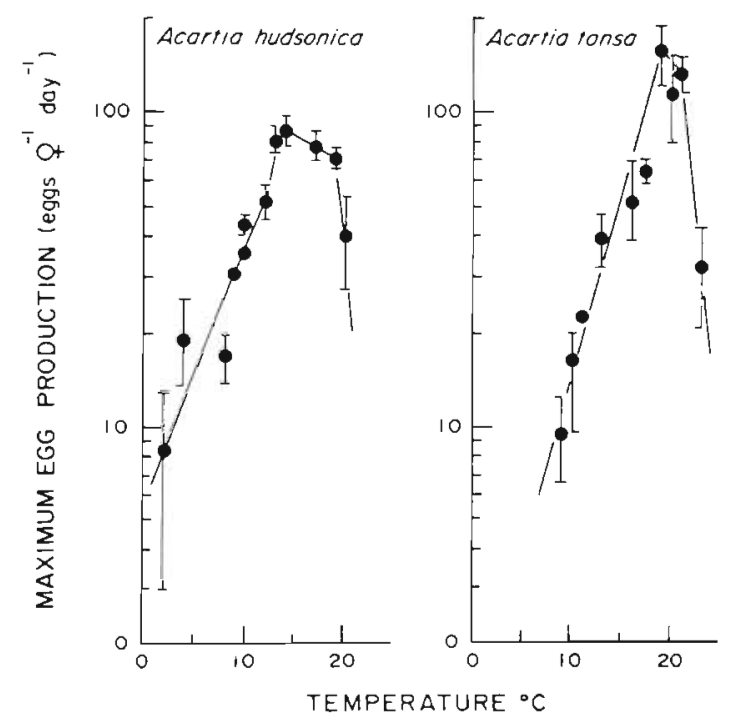

Fig. 2. Acartia hudsonica and A. tonsa. Relation between temperature and maximum rates of egg production females collected from MERL mesocosms. All data collected during the $2.5 \mathrm{yr}$ nutrient experiment were used to determine maximum rates. Mean and range of replicate values for the experiment in which the maxima were observed are plotted

those for which temperature was reduced sooner (Fig. 3).

The pattern of increasing production of resting eggs by Acartia hudsonica in June-July, while evident, is quite variable. Although available food supply (Chl a, Table 2) might influence type of eggs produced, and we are investigating this possibility, we believe that short term fluctuations in temperature of surface water $\left(17\right.$ to $\left.20^{\circ} \mathrm{C}\right)$, characteristic of this time of year, may be

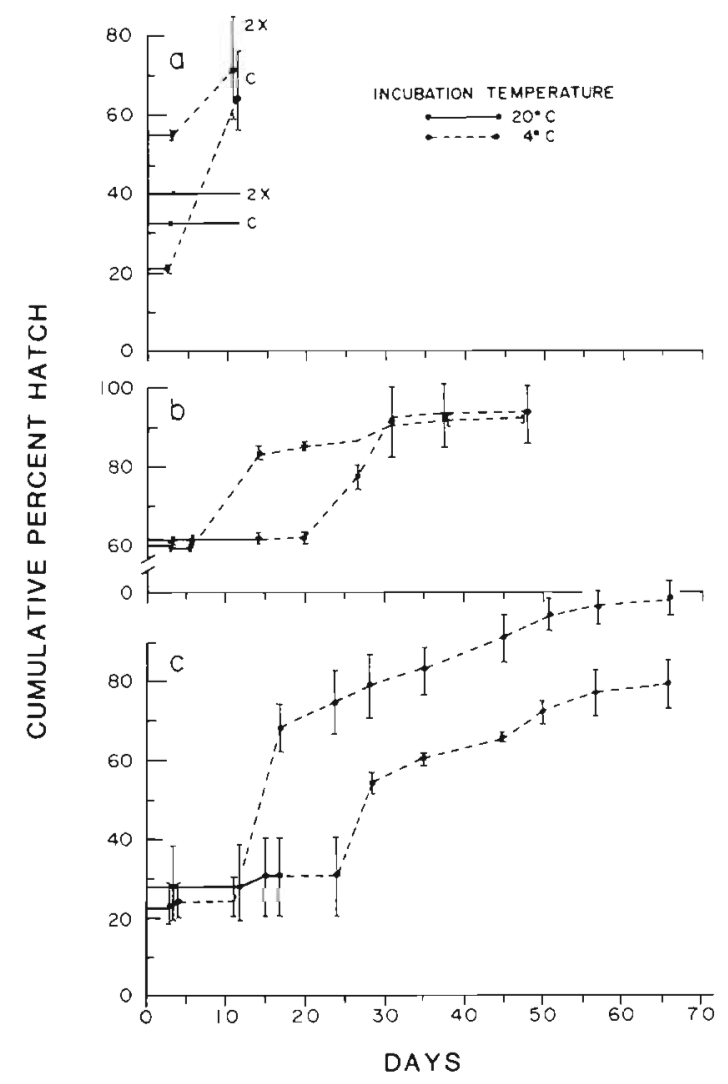

Fig. 3. Acartia hudsonica. Temperature-dependent hatch of resting eggs after hatch of subitaneous eggs that made up 20 to $60 \%$ of total eggs laid. All females are from control $(0 \times)$ MERL mesocosms unless specified $(2 \times$ nutrient treatment). Dates of egg collection: (a) July 13,1982; (b) July 19, 1984 ; (c) July 23, 1984. Mean and range of values from replicate incubation dishes indicated

Table 1. Acartia hudsonica and A.tonsa. Comparison of egg production and weight-specific egg production (\% body dry weight $\mathrm{d}^{-1}$ ) during periods in which both species co-occur. Females were obtained from MERL mesocosms of differing nutrient addition rates as indicated

\begin{tabular}{|c|c|c|c|c|c|c|}
\hline & \multirow{2}{*}{$\begin{array}{l}\text { Nutrient } \\
\text { treatment }\end{array}$} & \multirow{2}{*}{$\begin{array}{l}\text { Chl } a \\
\mu \mathrm{g} \mathrm{l}^{-1}\end{array}$} & \multicolumn{2}{|c|}{ Eggs female ${ }^{-1} \mathrm{~d}^{-1} \pm \mathrm{SD}$} & \multicolumn{2}{|c|}{ Weight-specific egg production $(\%)^{1}$} \\
\hline & & & A. hudsonica & A. tonsa & A. hudsonica & A. tonsa \\
\hline \multicolumn{7}{|l|}{ Summer: } \\
\hline \multirow[t]{5}{*}{$21 \mathrm{Jul}, 20^{\circ} \mathrm{C}$} & Control & 2.67 & 10.9 & $21.0 \pm 4.7$ & 9.0 & 14.5 \\
\hline & $1 \times$ & 6.07 & $18.6 \pm 0.9$ & $25.6 \pm 5.9$ & 16.2 & 17.4 \\
\hline & $2 \times$ & 13.44 & $40.9 \pm 8.8$ & $63.9 \pm 1.8$ & 27.6 & 31.7 \\
\hline & $4 \times$ & 18.22 & $42.0 \pm 14.6$ & $140.4 \pm 23.2$ & 28.3 & 71.8 \\
\hline & $16 \times$ & 8.91 & $24.2 \pm 4.1$ & $68.4 \pm 7.6$ & 19.9 & 37.9 \\
\hline \multicolumn{7}{|l|}{ Winter: } \\
\hline \multirow[t]{5}{*}{19 Nov, $9^{\circ} \mathrm{C}$} & Control & 1.58 & 10.6 & $8.2 \pm 5.6$ & 9.0 & 5.4 \\
\hline & $2 \times$ & 1.68 & $35.8 \pm 1.1$ & $17.6 \pm 2.8$ & 23.6 & 9.5 \\
\hline & $4 \times$ & 2.01 & - & 6.3 & - & 3.7 \\
\hline & $8 \times$ & 1.30 & 30.8 & 6.3 & 18.5 & 3.7 \\
\hline & $16 x$ & 2.81 & 14.3 & $10.2 \pm 2.7$ & 10.7 & 5.1 \\
\hline
\end{tabular}


Table 2. Acartia hudsonica. Summary of experiments to determine type (subitaneous or resting) of eggs laid. Initial hatch (mean and range) was the percent hatching after 5 to $17 \mathrm{~d}$ at ambient temperature. Final hatch was the cumulative total hatch after exposure of the unhatched portion to reduced temperature $\left(4^{\circ} \mathrm{C}\right)$. Number of replicates of 50 eggs each was 2 to 6 . Treatment refers to origin of females: control or nutrient-enriched MERL mesocosms

\begin{tabular}{|c|c|c|c|c|c|}
\hline Date & Treatment & $\begin{array}{l}\text { Chl a } \\
\mu \mathrm{g} \mathrm{l}^{-1}\end{array}$ & $\begin{array}{c}\text { Collection } \\
\text { temperature }\left({ }^{\circ} \mathrm{C}\right)\end{array}$ & $\begin{array}{c}\text { Initial hatch } \\
(\%)\end{array}$ & $\begin{array}{l}\text { Final hatch } \\
(\%)\end{array}$ \\
\hline \multicolumn{6}{|l|}{1982} \\
\hline $7 \mathrm{Jul}$ & $\mathrm{C}$ & 4.03 & 20 & $34.0(31-38)$ & - \\
\hline \multirow[t]{2}{*}{$13 \mathrm{Jul}$} & C & 2.12 & 20 & $24.9(20-32)$ & $64.0(56-72)$ \\
\hline & $2 x$ & 7.23 & 20 & $50.3(40-56)$ & $71.0(58-84)$ \\
\hline \multirow[t]{2}{*}{$19 \mathrm{Jul}$} & C & 1.22 & 20 & $25.0(24-26)$ & - \\
\hline & $2 \times$ & 2.03 & 20 & $21.0(10-32)$ & - \\
\hline \multicolumn{6}{|l|}{1983} \\
\hline 14 Jun & C & 1.62 & 18 & $83.3(80-85)$ & - \\
\hline 22 Jun & $\mathrm{C}$ & 0.89 & 18 & $65.0(50-80)$ & - \\
\hline 28 Jun & $C$ & 3.65 & 20 & $43.5(33-53)$ & - \\
\hline \multicolumn{6}{|l|}{1984} \\
\hline 20 Jun & $8 \times$ & 16.84 & 16 & $38.6(38-40)$ & - \\
\hline 28 Jun & $8 \times$ & 44.65 & 16 & $88.5(86-91)$ & - \\
\hline $19 \mathrm{Jul}$ & $8 x$ & 43.58 & 20 & $61.0(60-62)$ & $91.5(84-100)$ \\
\hline $23 \mathrm{Jul}$ & $8 \times$ & 4.27 & 20 & $26.0(18-38)$ & $89.0(72-104)$ \\
\hline \multicolumn{6}{|l|}{1985} \\
\hline $10 \mathrm{Mar}$ & $\mathrm{C}$ & - & 6 & $88.4(83-92)$ & - \\
\hline
\end{tabular}

responsible for the variability in proportion of resting eggs. We have preliminary evidence (unpubl. data) showing that exposure of the female to rapid temperature change causes a shift in egg type in less than $24 \mathrm{~h}$.

To determine whether resting or dormant eggs survive in the sediments, sediment cores were obtained from MERL mesocosms and Narragansett Bay and then incubated (Table 3, Fig. 4). Subitaneous (immediately hatching) eggs of both Acartia tonsa and $A$. hudsonica hatched from sediments collected and incubated at summer temperatures. After several days during which no further hatch was observed, the cores were transferred to low temperature. Eggs of only 1 species, $A$. hudsonica, hatched after incubation of the sediment at reduced temperature for $>1$ and $<5 \mathrm{~d}$. Cores collected in the winter and first incubated at low temperature produced $A$. hudsonica from subitaneous eggs after $2 \mathrm{~d}$. After hatching ceased the incubation temperature was raised and a hatch of $A$, tonsa from resting eggs was observed.

In general, more eggs hatched from sediments collected from nutrient enriched tanks than from control tanks (Table 3). The exception was during the first year of the nutrient enrichment experiment, 1981. There was no indication that Acartia hudsonica had increased its numbers of resting eggs in sediments collected during July 1981. There was also no increase in the population size of this species during the following winter and spring. It was only during the winter of
1983 that higher numbers of $A$. hudsonica were observed in nutrient enriched tanks.

We also collected data repeating the observations of Zillioux \& Gonzalez (1972) that Acartia tonsa produce eggs which are dormant in the winter (Table 4) and were able to find these eggs still viable in the sediments in May, prior to the appearance of adults in the water column (Table 3). Morphology of all eggs was similar except for occasionally spiny eggs. Eggs with spines were subitaneous only.

\section{DISCUSSION}

We have demonstrated that in Narragansett Bay the dominant winter-spring copepod, Acartia hudsonica, produces 2 kind of eggs, subitaneous (immediately hatching) and resting eggs, in mixed clutches, in early summer at temperatures $>16{ }^{\circ} \mathrm{C}$. The resting eggs do not hatch until they are exposed to lower temperatures typical of winter and spring, when $A$. hudsonica is most abundant in Narragansett Bay. These same kind of eggs were found in the sediments of Narragansett Bay (and in MERL tanks) during the summer and were induced to hatch only at low temperature. It is likely that production and delayed hatching of resting eggs are largely responsible for the seasonal disappearance of the species in summer when it is replaced by $A$. tonsa and its reappearance in early winter. In addition, 
Table 3. Acartia hudsonica and A. tonsa. Numbers of eggs hatched from sediment cores collected during (a) summer: cores collected and incubated at $20^{\circ} \mathrm{C}$ for $7 \mathrm{~d}$. Initial or subitaneous hatch produced both species. Subsequent incubation at $10^{\circ} \mathrm{C}$ from 5 to $30 \mathrm{~d}$ produced $A$. hudsonica only (final hatch). (b) Winter cores collected and incubated at $6^{\circ} \mathrm{C}$ for $23 \mathrm{~d}$. Initial hatch produced $A$. hudsonica; subsequent incubation at $16^{\circ} \mathrm{C}$ produced $A$. tonsa only (final hatch). Cores collected and incubated at $13^{\circ} \mathrm{C}$ produced both species

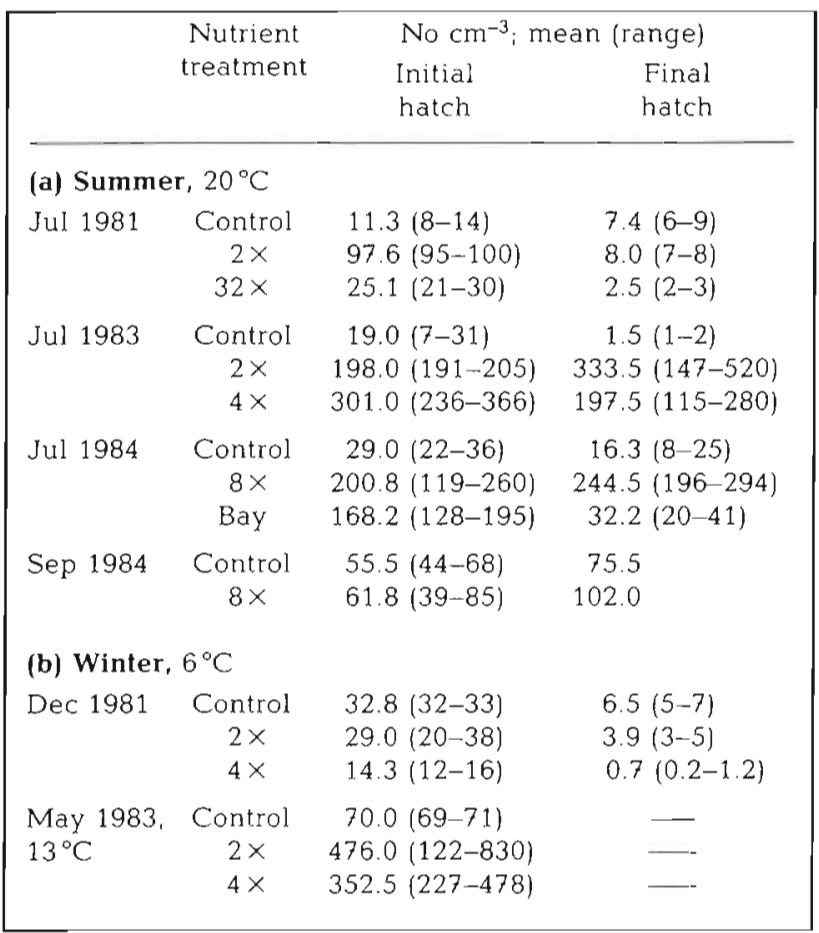

effects of temperature on the rate of reproduction probably explain the offset peaks in population size of $A$. hudsonica and $A$. tonsa. Other factors that also may contribute to the population decline, such as increased mortality of nauplii at summer temperatures, are not precluded by this study.

The Acartia clausi complex of species is widely distributed and these geographically disparate populations may be diverse in their response to temperature, particularly with regard to the production of resting eggs. Other investigators who have studied the effect of temperature on egg hatching of other members of the A. clausi complex (Landry 1975, 1978, Uye 1980) found no evidence for the type of eggs which we describe here. In Landry's study $90 \%$ or more of both winter and summer eggs hatched at $20^{\circ} \mathrm{C}$ in 27 to $31 \mathrm{~h}$. Temperatures in the lagoon from which Landry made his collections did reach 20 to $21^{\circ} \mathrm{C}$ in the summer, similar to the seasonal pattern in Narragansett Bay, although temperatures did not typically rise above $15^{\circ} \mathrm{C}$ in nearby waters of Puget Sound. Uye (1981, 1982) also reported that $A$. clausi in Onagawa Bay, Japan, produce only subitaneous eggs throughout the year despite a seasonal pattern of surface temperature rise to $20^{\circ} \mathrm{C}$ (but not until September-October). Temperature of maximum egg production was very similar $\left(17^{\circ} \mathrm{C}\right)$ to that found in our study. Further south in the Inland Sea of Japan, however, where temperatures reach $20^{\circ} \mathrm{C}$ in July, $A$. clausi do produce summer diapause eggs (Uye in press). It may be that only in the southern tip of its range do members of the $A$. clausi complex produce resting eggs. In waters north of $\mathrm{Nar}$ ragansett Bay where temperatures do not exceed 15 to $16{ }^{\circ} \mathrm{C}$ it is unlikely that resting eggs are formed. $A$.

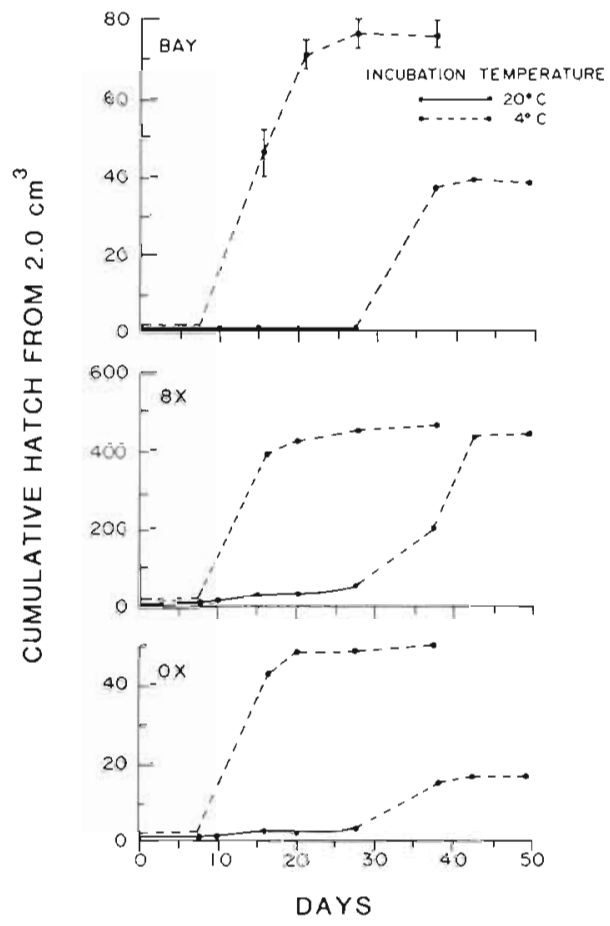

Fig. 4. Acartia hudsonica. Numbers of nauplii hatching from resting eggs in sediments collected from Narragansett Bay and MERL tanks. Collection date: July 26, 1984. Mean and

range of replicate cores indicated where appropriate

Table 4. Acartia tonsa. Decrease in numbers of immediately hatching eggs in clutches laid over a single season. Mean and range of 2 to 8 replicates of 50 to 100 eggs each are shown. Unhatched eggs were kept at $5^{\circ} \mathrm{C}$ for 4.0 mo before raising temperature to $18^{\circ} \mathrm{C}$ to determine final hatch

\begin{tabular}{|lrrcc|}
$\begin{array}{l}\text { Date } \\
1984\end{array}$ & $\begin{array}{c}\text { Treat- Collection } \\
\text { ment } \\
\text { temper- } \\
\text { ature }\left({ }^{\circ} \mathrm{C}\right)\end{array}$ & $\begin{array}{c}\text { Initial } \\
\text { hatch } \\
(\%)\end{array}$ & $\begin{array}{c}\text { Final } \\
\text { hatch } \\
(\%)\end{array}$ \\
\hline & & & & \\
$15 \mathrm{Jul}$ & $\mathrm{C}$ & 20 & $92.0(90.0-94.0)$ & - \\
$23 \mathrm{Jul}$ & $2 \times$ & 20 & $99.6(98.0-101.0)$ & - \\
$4 \mathrm{Aug}$ & $\mathrm{C}$ & 20 & $98.5(96.0-100.0)$ & - \\
$21 \mathrm{Sep}$ & $\mathrm{C}$ & 17 & $90.3(88.6-92.0)$ & - \\
13 Oct & $\mathrm{C}$ & 13 & $15.6(13.0-18.2)$ & - \\
13 Oct & $2 \times$ & 13 & $40.5(30.4-52.6)$ & - \\
$29 \mathrm{Nov}$ & Bay & 9 & $1.25(0-5.0)$ & $63.0(33-100)$ \\
\hline
\end{tabular}


hudsonica is in fact found year round in more northerly estuaries and is most abundant in the summer (Lee \& McAlice 1979), at the temperature we found maximum egg production

Although we have no direct proof that the summer dormant eggs are true diapause eggs, the fact that 2 different egg types responding differently to temperature are laid simultaneously indicates that the nonhatching eggs are true diapausing eggs. Nevertheless, these eggs do not fit the model of true diapause as described by Grice \& Marcus (1981). We found no evidence of a latent period which must be experienced before the egg can hatch even when exposed to a favorable environment (Grice \& Marcus 1981). The eggs produced in our experiments did not appear to require more than a few days exposure to warm temperatures before they would hatch at cold temperature. The time to hatch at cold temperature (about 7 to $8 \mathrm{~d}$ at $4{ }^{\circ} \mathrm{C}$ ) was approximately the normal time needed for a subitaneous egg laid at cold temperature to hatch $16 \mathrm{~d}$ at $5{ }^{\circ} \mathrm{C}_{i}$ McLaren 1978). Some of the eggs did take longer (Fig. 3) but all did eventually hatch. Another requirement of a true diapause egg defined by Grice \& Marcus (1981) is that it be produced by the female's response to some environmental cue and not merely a response of the egg to some adverse environmental factor, i.e. dormancy induced by low oxygen or unfavorable temperature. In this study we did not attempt to define whether eggs of $A$. hudsonica become dormant because of a response of the female or of the egg. The fact that we found subitaneous and dormant eggs being produced simultaneously and in increasing numbers during the spring suggests that there are indeed 2 types of eggs that respond differently to the same temperature at which they are laid.

Regardless of the mechanism by which the eggs are produced, the same ecological significance is implied: the production of dormant eggs or stages is apparently a means of avoiding temperatures at which it is difficult to maintain a successful population. For marine species dormancy more typically begins in fall or winter (Grice \& Marcus 1981), as is the case for Acartia tonsa. A. hudsonica is apparently avoiding temperatures above 18 to $20^{\circ} \mathrm{C}$ to which it is not well adapted. Our data do indicate a reduction in growth efficiency at higher temperatures reflected in reproductive rates that are less than maximum even under the food rich conditions that were found in nutrient-enhanced MERL tanks. Nevertheless, females can produce a relatively large number of eggs even at $20^{\circ} \mathrm{C}$. Since most of these are resting eggs, a substantial number of progeny are produced that will not hatch until ambient temperatures are more favorable to growth or when competition with other species such as $A$. tonsa is less.

It is not immediately obvious what selective advan- tage there might be for a marine species in total avoidance of a summer period in which no catastrophic environmental event occurs. Some freshwater calanoids produce summer diapausing eggs, but this probably is an adaptation to survive summer droughts (Brewer 1964) or avoid severe predation by fish during early summer (Hairston \& Munns 1984). Our study was not designed to distinguish among hypotheses concerning the selective pressure that makes abundance during cold temperatures and summer dormancy advantageous. It may be useful, however, to examine the particular environment of Narragansett Bay for scenarios that suggest viable hypotheses. First of all, food resources are more limiting in Narragansett Bay during the summer than in winter as evidenced by the winter phytoplankton bloom and summer low in diatom abundance (Smayda 1957). Egg production and population size of Acartia tonsa are food-limited in summer (Sullivan \& Ritacco 1985, Durbin et al. 1983). There is also very great predation pressure from large populations of ctenophores that are most abundant in July and August (Deason \& Smayda 1982). It may be that only a species like $A$. tonsa which has very high growth and reproductive efficiency at high temperature and low food levels can maintain a successful population in the face of this predation.

Because of the complete absence of ctenophores from MERL mesocosms which we observed during 1981-1983 despite high populations in Narragansett Bay during the same period, comparison of Acartia populations in MERL mesocosms versus Narragansett Bay provides important information concerning the role of ctenophores. Numbers of A. tonsa were much lower in Narragansett Bay than in the MERL mesocosms during the period of most intense predation, July-August (Fig. 1). The absence of ctenophores from the tanks probably accounts for this difference. Ctenophore predation may also explain the reduction in numbers of $A$. hudsonica in June in Narragansett Bay relative to numbers in the MERL tanks, as it is during this period that ctenophore numbers begin to increase in the Bay

If ctenophores exert a strong selection pressure, removal of the ctenophores in the MERL mesocosms might be expected to have reduced the selective advantage of summer dormancy. Rapid selection to alter the pattern in resting egg production over a few seasons only was observed by Hairston \& Munns (1984) for a winter-spring copepod species inhabiting small lakes. Reduction in predation pressure by fish was the apparent causal mechanism. At least during the $3 \mathrm{yr}$ period of the MERL study no change in timing of dormant egg production was evident. The slow inflow of water from Narragansett Bay would introduce new copepods and complicate the selection pattern, how- 
ever. Removal of the characteristic conditions of summer food limitation by nutrient enrichment also did not result in any change in the pattern of species succession during July and August. Thus, it appears that the environmental cue for production of resting eggs is most likely exposure to temperatures greater than $16{ }^{\circ} \mathrm{C}$, and that changes in predation pressure or food abundance do not quickly alter this pattern.

Acknowledgements. This study was supported by NOAA Grants NA82RAD00002 and NA83ABD00008. Data on abundances of copepods was made available by $P$. Lane and $P$. Fofonoff. Percy Donaghay and Candace Oviatt provided data on chlorophyll a. We thank P. Ritacco for help in collection of data on rates of egg production.

\section{LITERATURE CITED}

Bradford, J. M. (1976). Partial revision of the Acartia subgenus Acartiura (Copepoda: Calanoida Acartiidae). N.Z.Jl mar Freshwat. Res. 10: 159-202

Brewer, R. H. (1964). The phenology of Diaptomus stagnalis (Copepoda: Calanoida): the development and the hatching of the egg stage. Physiol. Zool. 37: 1-20

Conover, R. J. (1956). Oceanography of Long Island Sound 1952-1954. VI. Biology of Acartia clausi and A. tonsa. Bull. Bingham oceanogr Coll. 15: 156-233

Deason, E. E., Smayda, T. J. (1982). Ctenophore-zooplanktonphytoplankton interactions in Narragansett Bay, Rhode Island, USA, during 1972-1977. J. Plankton Res. 4: 203-217

Durbin, E. G., Durbin, A. G., Smayda, T. J., Verity, P. G. (1983). Food limitation of production of adult Acartia tonsa in Narragansett Bay, Rhode Island. Limnol. Oceanogr. 28 : $1199-1213$

Frithsen, J. B., Rudnick, D. T., Elmgren, E. (1983). A new, flow-through corer for quantitative sampling of surface sediments. Hydrobiologia 99: 75-79

Grice, G. D., Marcus, H. H. (1981). Dormant eggs of marine copepods. Oceanogr mar. Biol. A. Rev. 19: 125-140

Hairston, N. G. jr., Munns, W. R. jr. (1984). The timing of copepod diapause as an evolutionarily stable strategy Am. Nat. 123: 733-751

Jeffries, H. P. (1962). Succession of two Acartia species in estuaries. Limnol. Oceanogr. 7: 354-364

Landry, M. R. (1975). Seasonal temperature effects and predicting development rates of marine copepod eggs. Limnol. Oceanogr. 20: 434-440
Landry, M. R. (1978). Population dynamics and production of a planktonic marine copepod, Acartia clausii, in a small temperate lagoon on San Juan Island, Washington. Int Revue ges. Hydrobiol. 63: 77-119

Lee, W Y., McAlice, B. J. (1979). Seasonal succession and breeding cycles of three species of Acartia (Copepoda: Calanoida) in a Maine estuary. Estuaries 2: 228-235

McLaren, I. A (1978). Generation lengths of some temperate marine copepods: estimation, prediction, and implications. J. Fish. Res. Bd Can. 35: 1330-1342

Nixon, S. W., Pilson, M. E. Q., Oviatt, C. A., Donaghay, P., Sullivan, B., Seitzinger, S., Rudnick, D., Frithsen, J. (1984). Eutrophication of a coastal marine ecosystem - an experimental study using the MERL microcosms. In: Fasham, M. J. R. (ed.) Flows of energy and materials in marine ecosystems: theory and practice. Plenum Press, New York, p. $105-135$

Pilson, M. E. Q., Oviatt, C. A., Vargo, G. A., Vargo, S. L. (1979). Replicability of MERL microcosms: initial observations. In: Jacoff, F. S. (ed.) Advances in marine environmental research. Proc. of a Symp., June 1977, EPA-600/979-035, EPA, Narragansett, Rhode Island, p. 409

Pilson, M. E. Q., Oviatt, C. A., Nixon, S. W. (1980). Annual nutrient cycles in a marine microcosm. Giesy, J. P. (ed.) DOE Symposium Series, Augusta, Georgia, Nov. 8-10, 1978, CONF 781101, NTIS, U.S. Dept. of Commerce, Springfield, Virginia, p. 753-778

Smayda, T J. (1957). Phytoplankton studies in lower Narragansett Bay. Limnol. Oceanogr. 2: 342-359

Sullivan, B. K., Ritacco, P. J. (1985). The response of dominant copepod species to food limitation in a coastal marine ecosystem. Arch. Hydrobiol. Beih. Ergeb. Limnol. 21: in press

Uye, S. (1980). Development of neritic copepods Acartia clausi and A. steveri. I. Some environmental factors affecting egg development and the nature of resting eggs. Bull. Plankton Soc. Japan 27: 1-9

Uye, S. (1981). Fecundity studies of neritic calanoid copepods Acantia clausi Giesbrecht and A. steueri Smirnov: a simple empirical model of daily egg production. J. exp. mar. Biol. Ecol. 50: 255-271

Uye, S. (1982). Population dynamics and production of Acartia clausi Giesbrecht (Copepoda: Calanoida) in inlet waters. J. exp. mar. biol. Ecol. 57: 55-83

Uye, S. (in press). Resting egg production as a life history strategy of marine planktonic copepods. Bull. mar. Sci

Zillioux, E. J., Gonzalez, J. G. (1972). Egg dormancy in a neritic calanoid copepod and its implications to overwintering in boreal waters. In: Battaglia, B. (ed.) 5th European marine biology symposium. Piccin Editors, Padova, p. $217-230$ 